\title{
Ocular Trauma during Covid-19 Lockdown 2020 at Himalaya Eye Hospital
}

\section{Babita Gurung, Anju Gurung, Hara Maya Gurung, Eliya Shrestha, Hari Bikram Adhikari, Krishna Gurung and Pawan Baral*}

Himalaya Eye Hospital, Pokhara, Nepal

*Corresponding Author: Pawan Baral, Himalaya Eye Hospital, Pokhara, Nepal.
Received: July 05, 2021

Published: July 30, 2021

(C) All rights are reserved by Babita Gurung., et al.

\begin{abstract}
Purpose: To access the impact the COVID-19 lockdown had on the incidence of sight-threatening ocular trauma at Himalaya Eye Hospital, Nepal.

Methods: A retrospective study of all patients who underwent primary repair surgery for serious ocular trauma during the COVID-19 lockdown periods at Himalaya eye Hospital was performed. Data on demography of the patient, date of presentation, type of ocular trauma, laterality of the eye and surgical repair were collected. This process was repeated for the same dates in the previous year for comparison.

Results: Out of total 55 cases of ocular trauma requiring primary repair surgery at the main operating theatre, 12 cases were seen during the lockdown period. The mean age of patients with ocular trauma during the lockdown period was $40.5 \pm 5.54$ years. Fifty five cases of ocular trauma were also seen in the previous year while 16 cases of such ocular trauma were seen between dates $24^{\text {th }}$ March and $21^{\text {st }}$ July 2019. The mean age of patients with ocular trauma during this time was $29.06 \pm 3.48$ years.

Conclusion: During the COVID-19 lockdown, the number of serious ocular trauma cases was less than the previous year. This decrease is partially due to less outdoor injuries as people stayed at home due to lockdown.
\end{abstract}

Keywords: COVID Lockdown; Ocular Trauma; Primary Repair Surgery

\section{Abbreviations}

WHO: World Health Organization; COVID: Corona Virus Disease; OT: Operation Theater; RE: Right Eye; LE: Left Eye

\section{Introduction}

Ocular trauma, mainly open globe injury is one of the leading causes of ocular morbidity and monocular blindness in the world $[1,2]$. In Nepal, ocular trauma is the second leading cause of unilateral blindness after cataract, with 8.6/1,000 people having a history of ocular trauma $[3,4]$. Majority of the eye injuries occur at the workplace, followed by at home, sports-related and assault-related injuries. For work-related injuries, the construction industry is the most common setting for ocular trauma and grinding, cutting metal and drilling were the specific activities in more than $90 \%$ of cases. On $11^{\text {th }}$ March 2020, The World Health Organization (WHO) announced COVID-19 as a pandemic. Nepal introduced lockdown during the early phase of pandemic, from $24^{\text {th }}$ March to $21^{\text {st }}$ July 2020. Initially there was prohibition of domestic and international travels, border closures, and shutting down of nonessential services, which was later eased on 11 June 2020 [1]. The COVID-19 lockdown drastically reduced the movement of industrial activity, closed schools, shops and restaurants which brought a normal life to a standstill.

\section{Aim of the Study}

Through this study we aimed to determine if there was a difference in incidence of ocular injuries occurring in lockdown com- 
pared to the previous year.

\section{Materials and Methods}

This hospital based retrospective study was conducted after obtaining approval from the Himalaya Eye Hospital. Data were collected retrospectively through records of Himalaya Eye Hospital between $24^{\text {th }}$ March 2020 (i.e. the day on which the lockdown was issued in our country) and $21^{\text {st }}$ July 2020 and confronted with those of the same period of the previous year (from 24 March 2019 to 21 July 2019). In order to have a better comparison of the types and number of ocular injuries between 2 years, we also collected the details of the types and number of ocular injuries that needed primary repair surgery in year 2019 and 2020.

Inclusion criteria: Ocular injuries requiring surgical repair in main Operation Theater (OT) like globe ruptures, full-thickness lid lacerations, corneal lacerations, and intra-ocular foreign bodies were included in the study.

Exclusion criteria: Ocular injuries that did not require surgical repair were not included in the study.

\section{Data collection and statistical analysis}

The data was initially collected from hospital records to find cases and later from OT record file, for those who went through primary repair surgery. The details for patients' demographic in- formation including age, gender, ethnicity, address, laterality of eye, and type of injury were collected as the variables for the study.

The data collected was then entered in Microsoft Excel and analyzed in the same.

\section{Results}

During the period from March 2019 to February 2020 there were 55 ocular trauma cases who underwent primary repair surgery at the main OT of HEH. Of those 55 cases 16 cases had presented from date $24^{\text {th }}$ March to $21^{\text {st }}$ July. The mean age of patients with ocular trauma between dates $24^{\text {th }}$ March and $21^{\text {st }}$ July 2019 was $29.06 \pm 3.48$ years.

During the period from March 2020 to February 2021 there were also 55 ocular trauma cases who underwent primary repair surgery at the main OT of HEH. Of those 55 cases 12 cases had presented from date $24^{\text {th }}$ March to $21^{\text {st }}$ July 2021, which was the lockdown period issued by the government of Nepal. The mean age of patients with ocular trauma during the lockdown period was 40.5 \pm 5.54 years. On comparison using an independent $t$ test, there was no significant effect for age and ocular injury $\mathrm{t}(19)=-1.831, \mathrm{p}=$ .078 despite the mean age of patients during lockdown period in 2020 was on a higher side. The details of the ocular injuries and comparison between two years is given in table 1 and 2 .

\begin{tabular}{|c|c|c|c|c|c|c|c|c|c|c|c|}
\hline & 2019 & 2020 & & 2019 & 2020 & & 2019 & 2020 & & 2019 & 2020 \\
\hline Gender & & & & & & Dis & ricts & & Type of Injury & & \\
\hline Male & 46 & 43 & 0 to 18 & 15 & 7 & Kaski & 22 & 26 & Corneal FB & 7 & 4 \\
\hline Female & 9 & 12 & 19 to 29 & 13 & 14 & Lamjung & 1 & 1 & Corneal perforation & 21 & 21 \\
\hline Mean age & $34.13 \pm 2.78$ & $39.65 \pm 17.43$ & 30 to 39 & 7 & 6 & Parbat & 2 & 4 & Lid laceration & 11 & 13 \\
\hline & & & 40 to 49 & 7 & 9 & Baglung & 11 & 9 & Globe rupture & 2 & 0 \\
\hline & & & 50 to 59 & 4 & 11 & Myagdi & 4 & 5 & Penetrating Eye Injury & 7 & 11 \\
\hline & & & 60 to 69 & 5 & 8 & Tanahun & 6 & 5 & Open globe injury & 1 & 0 \\
\hline & & & $\begin{array}{l}70 \text { and } \\
\text { above }\end{array}$ & 4 & 0 & Syangja & 7 & 3 & Subconjunctival foreign body & 2 & 0 \\
\hline & & & & & & Gorkha & 1 & 1 & Scleral perforation & 1 & 4 \\
\hline & & & & & & Manang & 1 & 0 & Canaliculi laceration & 1 & 0 \\
\hline & & & & & & $\begin{array}{l}\text { Nawal- } \\
\text { parasi }\end{array}$ & 0 & 1 & Lens dislocation & 1 & 1 \\
\hline & & & & & & & & & Conjunctival laceration & 1 & 0 \\
\hline & & & & & & & & & Traumatic cataract & 0 & 1 \\
\hline Total & 55 & 55 & & 55 & 55 & & 55 & 55 & & 55 & 55 \\
\hline
\end{tabular}

Table 1: Comparison of ocular trauma between years 2019 and 2020. 


\begin{tabular}{|c|c|c|c|c|c|c|c|c|}
\hline & 2019 & 2020 & Type of Injury & 2019 & 2020 & Districts & 2019 & 2020 \\
\hline Gender & & & Corneal FB & 3 & 0 & Kaski & 3 & 3 \\
\hline Male & 13 & 9 & Corneal perforation & 3 & 5 & Lamjung & 0 & 0 \\
\hline Female & 3 & 3 & Lid laceration & 4 & 2 & Parbat & 1 & 2 \\
\hline Mean age & $29.06 \pm 3.48$ & $40.5 \pm 5.54$ & Globe rupture & 1 & 0 & Baglung & 4 & 4 \\
\hline $\mathrm{RE}$ & 6 & 4 & Penetrating Eye Injury & 3 & 3 & Myagdi & 2 & 2 \\
\hline \multirow[t]{7}{*}{ LE } & 10 & 8 & Open globe injury & 1 & 0 & Tanahun & 4 & 0 \\
\hline & & & Subconjunctival foreign body & 0 & 0 & Syangja & 2 & 1 \\
\hline & & & Scleral perforation & 0 & 1 & Gorkha & 0 & 0 \\
\hline & & & Canaliculi laceration & 0 & 0 & Manang & 0 & 0 \\
\hline & & & Lens dislocation & 0 & 1 & Nawalparasi & 0 & 0 \\
\hline & & & Conjunctival laceration & 1 & 0 & & & \\
\hline & & & Traumatic cataract & 0 & 0 & & & \\
\hline Total & 16 & 12 & & 16 & 12 & & 16 & 12 \\
\hline
\end{tabular}

Table 2: Comparison of ocular trauma during lockdown period in 2020 and same time in 2019.

\section{Discussion}

Many studies have assessed the effect of COVID-19 lockdown with reference to disease prevention [5] environment, and emotional and psychological conditions [6]. The current study focused on the effect of COVID-19 lockdown on the incidence of ocular trauma.

There was a decrease in the number of eye injuries seen in our hospital during lockdown period compared to previous year. This study favors the other reports from America, Italy, and Germany which also reported a decrease in numbers of ocular trauma during lockdown period [7]. This may be due to behavioral changes during the quarantine, decrease of sport injuries due to school closure and decrease in work-related injuries due to halt of work at industries and outdoors. We believe that some patients may intentionally avoid urgent care due to fear of risking corona virus exposure at hospitals. Irrespective of the country of origin, there is a universal pattern of more risk in young adult males [8]. The higher risks in young men appear to reflect a combination of a higher risk of workrelated, assault related, sports-related and motor vehicle crash-related ocular injuries [9]. This study also shows the dominance of male gender for ocular trauma.

Himalaya Eye hospital is a tertiary eye hospital situated in Kaski district and patients from neighbouring districts are referred to the hospital. Majority of the ocular trauma patients were from neigh- bouring districts, suggesting that patients were seeking better ocular management despite of the Covid-19 lockdown. It is also a possibility that the lockdown was strictly followed in urban districts like Kaski compared to other districts.

\section{Conclusion}

Ocular trauma was lowered during lockdown but resulted in significant cause of primary repair surgery, which is a major cause of vision loss.

\section{Acknowledgements}

The authors would like to acknowledge the support provided by Himalaya Eye Hospital in conducting this study.

\section{Conflict of Interest}

None.

\section{Bibliography}

1. Sharma K., et al. "Assessment of COVID-19 Pandemic in Nepal: A Lockdown Scenario Analysis". Med Rxiv (2020).

2. Parver LM. "Eye Trauma: The Neglected Disorder". Archives of Ophthalmology 104.10 (1986): 1452-1453.

3. Brilliant LB., et al. "Epidemiology of blindness in Nepal". Bulletin of the World Health Organization 63.2 (1985): 375-386. 
4. Khatry SK., et al. "The epidemiology of ocular trauma in rural Nepal". The British Journal of Ophthalmology 88.4 (2004): 456460 .

5. Piryani RM., et al. "Nepal's Response to Contain COVID-19 Infection". Journal of Nepal Health Research Council 18.1 (2020): 128-134.

6. Tomar A and Gupta N. "Prediction for the spread of COVID-19 in India and effectiveness of preventive measures". The Science of the Total Environment 728 (2020): 138762.

7. Pellegrini M., et al. "Changing trends of ocular trauma in the time of COVID-19 pandemic”. Eye 34.7 (2020): 1248-1250.

8. Thylefors B. "Epidemiological patterns of ocular trauma". Australian and New Zealand Journal of Ophthalmology 20.2 (1992): 95-98.

9. Voon LW., et al. "The epidemiology of ocular trauma in Singapore: Perspective from the emergency service of a large tertiary hospital". Eye 15.1 (2001): 75-81.

Volume 4 Issue 8 August 2021

(C) All rights are reserved by Babita Gurung., et al. 